\title{
Development of a New Heat Exchanger for the Super Cooling (HESC) to Enhance the Performance of the Heat Pump System for the Living Space by the Natural Energy
}

\author{
Song, Heon* \\ *21 BMFA Natural Energy Development(archilieu@hotmail.com)
}

\section{자연에너지를 이용한 생활공간 냉난방용 열펌프의 성능향상을 위한 과냉 촉진 신개념 열교환기(HESC) 개발}

송 헌*

*21 BMFA 자연에너지 개발(archilieu@hotmail.com)

\begin{abstract}
과냉 촉진을 위한 새로운 열교환기(HESC)가 생활공간의 냉난방을 위한 공기-물 열펌프의 성능계수 향상을 위해 본 연구에서 개발되었으며 그 효과를 실험적으로 분석하였다. 이 열교환기(HESC)는 여러 단계의 셀과 튜 브로 구성되어 있으며, 열펌프 시스템의 응축기와 증발기 사이에 장착되었다. 실험 조건으로, 외기온은 $7^{\circ} \mathrm{C}$ 에서 $-17^{\circ} \mathrm{C}$, 입구 물 온도는 $7 \sim 10^{\circ} \mathrm{C}$ 그리고 제 2 열전달매체로서 물의 질량 유동율은 시간당 100 에서 $300 \ell$ 로 변화 를 주었다. 본 실험에서 이 열교환기가 장착된 열펌프의 압축기에서의 냉매 입·출구 사이의 온도 차이는 열교환 기가 장착되지 않은 열펌프보다 $15^{\circ} \mathrm{C}$ 높았다. 이에 따라 이 열교환기가 장착된 열펌프 시스템은 외기온 $-10^{\circ} \mathrm{C}$ 에서 $\mathrm{COP}$ 가 0.8 증가하였다. 따라서 이 공기-물 열펌프 시스템은 최근 한국에서 실용화되고 있는 고비용이 요구 되는 지열 열펌프 시스템을 대체하여 생활공간을 위한 냉난방 시스템으로서 중요한 역할을 할 수 있을 것으로 사료된다.
\end{abstract}

Keywords : 과냉 촉진 열교환기(Heat Exchanger for the Super Cooling(HESC)), 생활공간(Living Space), 자연에너지 (Natural Energy), 공기-물 열펌프 시스템(Air-to-Water Heat Pump System), 성능계수(COP)

투고일자 : 2011년 9월 14일, 심사일자 : 2011년 9월 17일, 게재확정일자 : 2011년 12월 12일 교신저자 : 송헌(archilieu@hotmail.com) 


\section{Nomenclature}

\begin{tabular}{|c|c|}
\hline$Q_{\text {gain }}$ & $\begin{array}{l}\text { : heat gain of the new system } \\
\text { circuit with } \mathrm{HESC}(\mathrm{kca} / \mathrm{hr})\end{array}$ \\
\hline$Q_{\mathrm{EVA}, \mathrm{gc}}$ & $\begin{array}{l}\text { heat absorbed from } \\
\text { evaporator in the general } \\
\text { circuit without HESC }(\mathrm{kca} / \mathrm{hr})\end{array}$ \\
\hline$Q_{\text {comp }}$ & $\begin{aligned} & \text { power consumption of } \\
& \text { compressor }(\mathrm{kcal} / \mathrm{hr})\end{aligned}$ \\
\hline$\Delta \mathrm{Q}_{\mathrm{HESC}}$ & $\begin{array}{l}\text { : heat gain increased by the } \\
\text { HESC }(\mathrm{kcal} / \mathrm{hr})\end{array}$ \\
\hline Q Loss $_{1}$ & $\begin{array}{l}: \text { the other heat loss from the } \\
\text { heat pump system }(\mathrm{kcal} / \mathrm{hr})\end{array}$ \\
\hline qLoss & $\begin{array}{l}\text { : heat loss per unit mass of } \\
\text { refrigerant }(\mathrm{kcal} / \mathrm{kg})\end{array}$ \\
\hline $\mathrm{G}_{0}$ & $\begin{array}{l}\text { : mass flow rate of refrigerant } \\
(\mathrm{kg} / \mathrm{hr})\end{array}$ \\
\hline$\Delta \mathrm{h}$ & $\begin{array}{l}\text { : enthalpy difference between } \\
\text { two conditions }(\mathrm{kcal} / \mathrm{kg})\end{array}$ \\
\hline $\mathrm{COP}_{\text {gain }}$ & $\begin{array}{l}\text { : COP of new circuit with } \\
\text { HESC }\end{array}$ \\
\hline $\mathrm{COP}_{\mathrm{gc}}$ & $\begin{array}{l}\text { : COP of the general circuit } \\
\text { without HESC }\end{array}$ \\
\hline$\Delta \mathrm{COP}_{\mathrm{HESC}}$ & : COP increased by HESC \\
\hline Ev.i & : Inlet of evaporator \\
\hline Ev.o & : Outlet of evaporator \\
\hline S.i & $\begin{array}{l}\text { : Inlet of shell in HESC or } \\
\text { By-pass }\end{array}$ \\
\hline S.o & $\begin{array}{l}\text { : Outlet of shell in HESC or } \\
\text { By-pass }\end{array}$ \\
\hline Cm.i & : Inlet of compressor \\
\hline Cm.o & : Outlet of compressor \\
\hline Cd.i & : Inlet of condenser \\
\hline Cd.o & : Outlet of condenser \\
\hline T.i & $\begin{array}{l}\text { : Inlet of tube in HESC or } \\
\mathrm{By}^{-} \text {pass }\end{array}$ \\
\hline T.O & $\begin{array}{l}\text { Outlet of tube in HESC or } \\
\text { By-pass }\end{array}$ \\
\hline Ex.i & : Inlet of expansion valve \\
\hline Ex.o & : Outlet of expansion valve \\
\hline
\end{tabular}

\section{Introduction}

The human beings have been faced with the double difficulties of the high oil prices and environmental pollution caused by the fossil fuel.

In order to solve these problems, all over the world renewable energy projects are in progress to develop the system using the alternative energy resources.

In U.S.A. and Brazil, ethanol developed as a transport fuel from corn and sugar cane is one of the factors to raise the prices of sugar and animal feed.

In Europe, Japan, and South Korea, scientists are immersed in realization of the wind power, solar cell (photovoltaic system) systems, and geothermal heat pump system, and especially the Korean Government proposed the national programs of "the low carbon and high green growth" for the development of renewable energy.

Even if the wind power and solar cell systems could be relatively good complements for the natural energy utilization, there are some difficulties in converting the sunrays into the clean and reliable energy. For example, the efficiency of solar cell is limited to $13 \%$ and the installation cost of the system is too high as compared with air-to-water heat pump system.

In general, the energy storage system is inevitable for the solar energy utilization. Fortunately, solar energy is stored abundantly in the air, the earth and the water. Unfortunately, however, the temperature variation of the solar energy stored in the air according to the regions and seasons is one of the troubled factors for the realization of solar energy systems.

In case of the air-to-water heat pump system using the energy stored in the ambient air as the heat source, the coefficient of performance would rapidly decrease below $-10^{\circ} \mathrm{C}$ of the 
ambient air temperature.

In the review of the literature, to solve these problems solar assisted heat pump on air collectors has been developed aiming at maximizing the efficiency of the solar air collector, as well as minimizing decrease of air-to-water heat pump performance due to the rapid decrease of the ambient air temperature (Karagiorgas et al., 2008).

In addition, a new photovoltaic/thermal heat pump system having a modified collector/ evaporator has been developed and numerically studied to prove that the heat output of the system could be used to provide domestic hot water heating and/or space heating (Ito et al., 1997, Xu et al., 2009). There are many causes for seasonal performance degradation. In the heating season, performance reductions are caused by reduced system efficiency at low outdoor temperature, and frosting of the outdoor coil.(N.B.M. stefanuk et al, 1990)

In this study, in order to solve these problems, the HESC (Heat Exchanger for Super-Cooling) was developed and adapted to the air-to-water heat pump system and the characteristics of performance of this system were analyzed.

\section{The composition of the air-to-water heat pump and analysis of the thermal energy balance}

\subsection{Air- to-water heat pump circuit.}

The air-to-water heat pump circuit is composed as shown in Fig. 1. It consisted of compressor, evaporator, HESC, condenser, two expansion valves and four-way valve to change the direction of the refrigerant flow in the circuit for heating and cooling.

It is different from the already existent heat pump circuit in that the HESC was

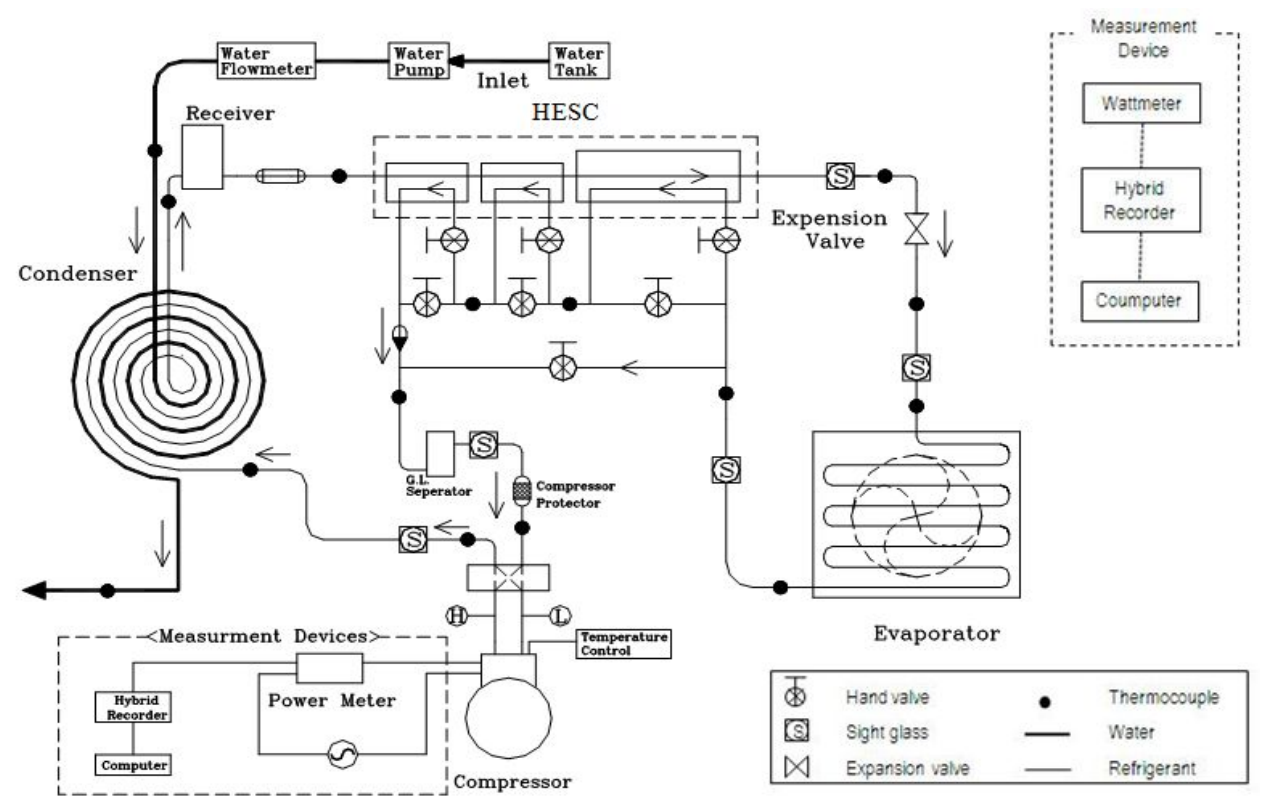

Figure 1. Air-to-water heat pump circuit installed with HESC and experimental apparatus 
inserted between the condenser and evaporator for the extension of the super heating and cooling process. HESC is composed of multistage shell and tubes and solenoid valves.

\subsection{Description of the HESC}

In order to prevent the COP decrease of air source heat pump system at the ambient temperature below $-10^{\circ} \mathrm{C}$, the $\mathrm{HESC}$ as a new heat exchanger was developed in this study.

As shown in Fig.3, the COP could be increased with the part of super cooling and heating extended by the HESC in condensing process. In addition, the temperature decrease of the second working fluid as water heated through the condenser could be controlled.

The configuration details of HESC and TIC auto-control flow chart for the operation of HESC could be described as follows:

(1) Configuration details of the HESC

As shown in Fig.2 (a), in order to change the heat exchange area automatically the HESC was composed of 3 stages of the shell and tubes type heat exchanger.
In order to control the flow direction of the refrigerant as working fluid, two 3-way valves, one 2-way valve, and by-pass were installed on the HESC.

And to operate the HESC automatically, the TIC auto-control circuit was attached to the HESC.

(2) Automatic operation of the HESC

As shown in Fig.2 (a), HESC is a kind of shell-and-tube heat exchanger with three shell pass and multi-tube pass operating automatically as counter flow mode.

As shown in Fig.2 (b), the refrigerant flows continuously from the condenser to the evaporator through the multi-tube pass.

On the other hand, it flows from the evaporator to the compressor through the shell pass and by-pass, and then the direction of shell pass could be changed by the control (open and close) of V1, V2 and V3.

The valves V1, V2 and V3 could be controlled by the TIC auto-control flow chart to increase the heat exchange area of the HESC composed of 3 stages heat exchanger.

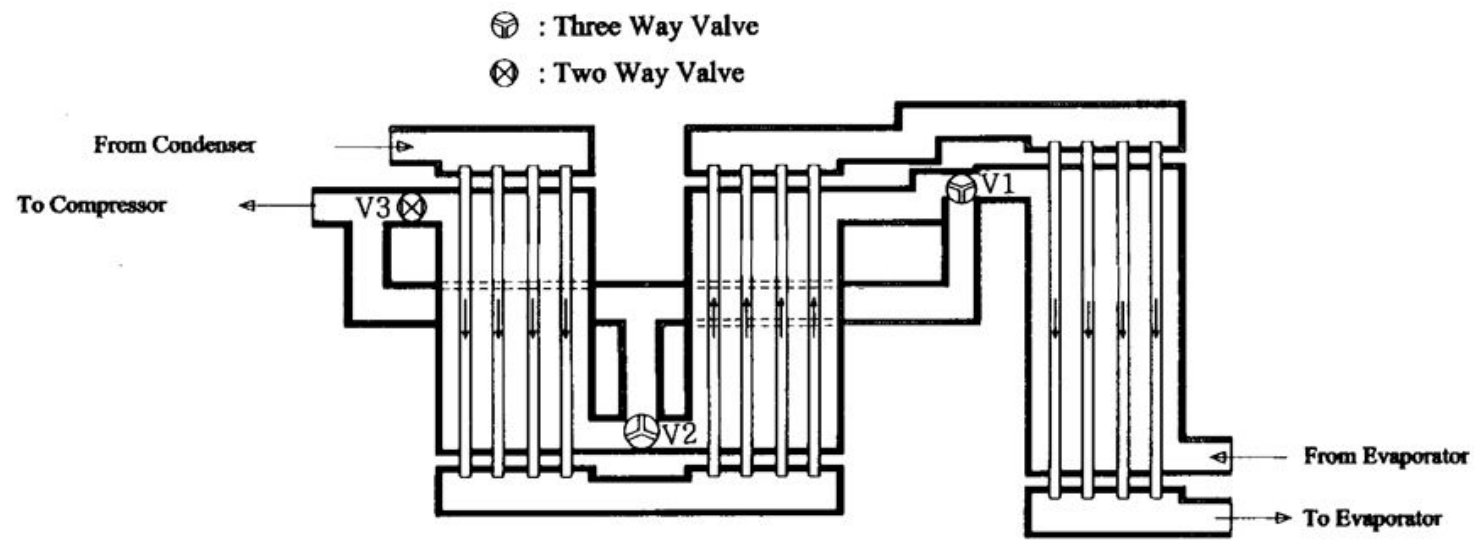

Figure 2(a). Configuration details of the HESC 


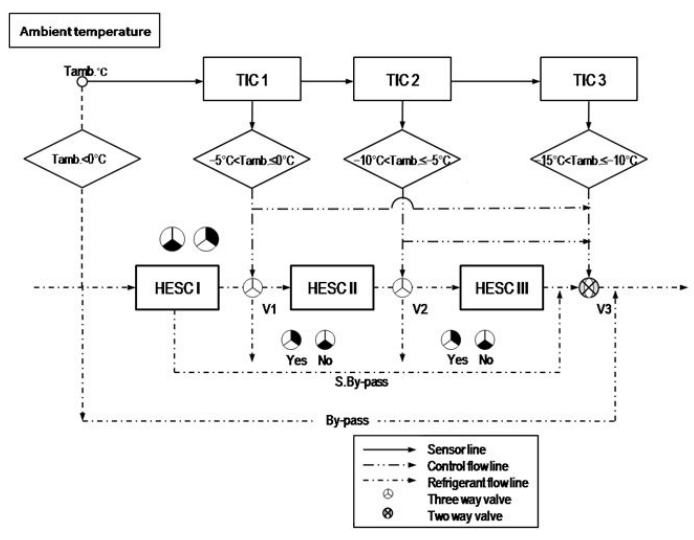

Figure 2(b). TIC auto-control flow chart for the HESC operation.

The automatic operation of the HESC according to the ambient temperature can be described as follows:

In case of the ambient temperature of $T_{\text {amb. }} \geq 0^{\circ} \mathrm{C}$, the refrigerant inflows directly to the compressor not passing the HESC.

In case of the ambient temperature of $-5^{\circ} \mathrm{C}<\mathrm{T}_{\text {amb. }} \leq 0^{\circ} \mathrm{C}$, the valve $\mathrm{V} 1$ is opened to the by-pass and closed to the shell pass of $\mathrm{H}$ II, so the refrigerant flows from the evaporator to the compressor through the shell pass of H I. Consequently, the HESC operates as only One-stage shell-and-tube heat exchanger.

In case of the ambient temperature of $-10^{\circ} \mathrm{C}<\mathrm{T}_{\text {amb. }} \leq-5^{\circ} \mathrm{C}$, the valve $\mathrm{V} 1$ is opened to the shell pass of $\mathrm{H}$ II and the valve V2 is opened to the by-pass, so the refrigerant flows from the evaporator to the compressor through two-stage shell passes of $\mathrm{H} \mathrm{I}$ and $\mathrm{H} \mathrm{II}$.

In case of the ambient temperature of

$-15^{\circ} \mathrm{C}<\mathrm{T}_{\mathrm{amb}} \leq-10^{\circ} \mathrm{C}$, the valve $\mathrm{V} 1$ is opened to the shell pass of $\mathrm{H}$ II, the valve V2 opened to the shell pass of H III and valve V3 opened to the compressor, so the

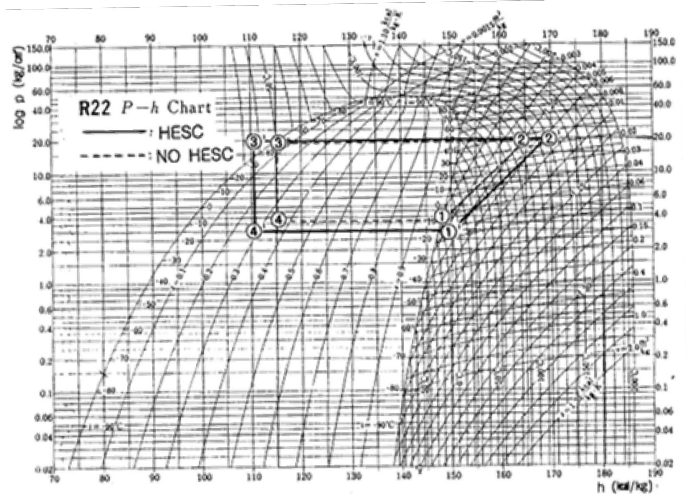

Figure 3. The air-to-water heat pump cycle installed with and without the HESC on the $R_{22} p-h$ chart

refrigerant flows from the evaporator to the compressor through the 3 -stage shell passes of $\mathrm{H} \mathrm{I}, \mathrm{H}$ II, and $\mathrm{H}$ III.

Consequently, the HESC operates as a 3-stage shell-and-tube heat exchanger.

All of the operations mentioned above could be controlled by the TIC auto-control flow chart as shown in Fig.2(b).

(3) The air-to-water heat pump cycle on the $R_{22} p^{-h}$ chart

The heat pump cycle installed with and without the HESC on the $\mathrm{R}_{22} \mathrm{p}^{-} \mathrm{h}$ chart is as shown in Fig.3 where the dotted line (1)-(2)(3)-(4) is the existent heat pump cycle without the HESC and the solid line (1)'-(2)'-(3)'-(4) is new air-to-water heat pump cycle installed with the HESC. In the condensing process of (2)-(3), (3)-(3)' is a part of super cooling and (2) -(2) a part of super heating extended by the HESC.

\subsection{Heat balance and coefficient of performance (COP)}

The heat balance and COP gained by the HESC on the $p^{-h}$ diagram of heat pump 
cycle could be equated as follows. (Fig. 3)

(1) Heat balance of heat pump installed with HESC

$\dot{Q}_{\text {gain }}=\dot{Q}_{E V A . g c}+\dot{Q}_{\text {comp }}+\triangle \dot{Q}_{H E S C}-\dot{Q}_{\text {Loss }}$

$\dot{Q}_{\text {gain }}=\dot{G}_{0}\left(\Delta h_{1-4}+\Delta h_{2-1}+\Delta h_{3-3^{\prime}}+\Delta h_{2^{\prime}-2}-q_{\text {Loss }}\right)$

(2) Coefficient of performance (COP).

- COP of the new the heat pump cycle installed with HESC.

$$
\begin{aligned}
& C O P_{\text {gain }}=C O P_{g c}+\triangle C O P_{H E S C} \\
& C O P_{g c}=\frac{\Delta h_{2-3}-q_{\text {Loss }}}{\Delta h_{2-1}} \\
& C O P_{g a i n}=\frac{\Delta h_{2^{\prime}-3^{\prime}}-q_{\text {Loss }}}{\Delta h_{2^{\prime}-1^{\prime}}} \\
& \triangle h_{2^{\prime}-1^{\prime}} \cong \Delta h_{2-1} \\
& \triangle C O P_{H E S C}=\frac{\Delta h_{2^{\prime}-3^{\prime}}-\Delta h_{2-3}}{\Delta h_{2-1}}
\end{aligned}
$$

In the equation $(1) \sim(5), \Delta \mathrm{Q}_{\mathrm{HESC}}$ and $\triangle \mathrm{COP}_{\mathrm{HESC}}$ are the heat gained and COP increased by HESC, respectively.

(3) The effect of the HESC on the COP

As shown in the equations (1) (5), it was possible to analyze that the heat gain and COP of the heat pump system could be increased by the HESC installed between the evaporator and the condenser (Fig.1).

\section{Experimental equipment and method}

In order to analyze experimentally the coefficient of performance (COP) of the heat pump system installed with the HESC, the experimental equipment and variable factors are provided as shown in Fig.4 and Table 1.

\subsection{Experimental equipment}

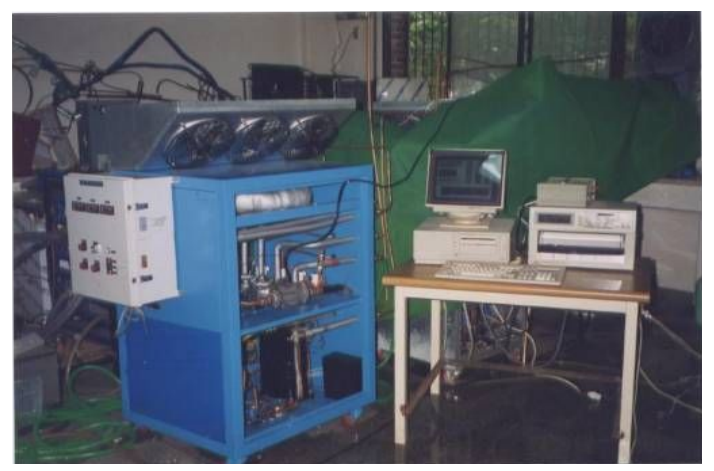

Figure 4. Experimental equipment of heat pump system (3PS).

The circuit of the air-to-water heat pump system and the experimental equipment were composed as shown in Fig. 1. 15 thermocouples(TM-B type) were fixed to measure the temperatures at the inlet and outlet of refrigerant and water circuit as shown in Fig. 1. All of the temperatures sensed by thermocouples could be recorded automatically on the hybrid recorder(Type 8H12, made by NEC san-ei inst. Ltd in JAPAN).(Fig.4) A water flow meter was set up in the water circuit to measure the water mass flow rate. The suction and discharge pressure of the scroll compressor was observed by installing high and low pressure gauges in circuit. To observe the phase change state of refrigerant, 5 sight glasses were equipped in the refrigerant circuit and to measure the power consumption of the scroll type compressor of 3PS employed 


\begin{tabular}{|c|c|c|c|c|c|c|}
\hline $\begin{array}{l}\text { Variables } \\
\text { Items }\end{array}$ & $\begin{array}{l}\text { Ambient air } \\
\text { temp. }\left({ }^{\circ} \mathrm{C}\right)\end{array}$ & $\begin{array}{l}\text { Water inlet } \\
\text { temp. }\left({ }^{\circ} \mathrm{C}\right)\end{array}$ & $\begin{array}{l}\text { Water flow } \\
\text { rate }(1 / \mathrm{h})\end{array}$ & $\begin{array}{c}\text { Refrigerant } \\
\text { low, high } \\
\text { pressure } \\
\left(\mathrm{kg} / \mathrm{cm}^{2}\right)\end{array}$ & Measuring items & Test interval \\
\hline \multirow{2}{*}{ HESC } & $-14 \sim 4$ & $7 \sim 10$ & $100 \sim 300$ & $3, \quad 18$ & \multirow{4}{*}{$\begin{array}{l}\text { Temperature of } 15 \\
\text { points in the water } \\
\text { and refrigerant } \\
\text { circuit } \\
\text { Electric power } \\
\text { consumption }\end{array}$} & \multirow{4}{*}{30 min. } \\
\hline & $-17 \sim 7$ & $7 \sim 10$ & $100 \sim 300$ & $3, \quad 18$ & & \\
\hline \multirow{2}{*}{ By-pass } & $-14 \sim 4$ & $7 \sim 10$ & $100 \sim 300$ & $3, \quad 20$ & & \\
\hline & $-17 \sim 7$ & $7 \sim 10$ & $100 \sim 300$ & $3, \quad 20$ & & \\
\hline
\end{tabular}

Table 1. Combination of variables and measuring items

in this system, the watt meter(VIP, V3 type made in Italy) as the energy analyzer was employed.

\subsection{Experimental method}

To analyze the coefficient of performance (COP) of the air-to-water heat pump system, the variables and measuring items could be combined as shown in Table 1 .

\section{Results and discussion}

4.1. The HESC effect on the inlet and outlet temperature of refrigerant circulating in the main of the heat pump circuit.

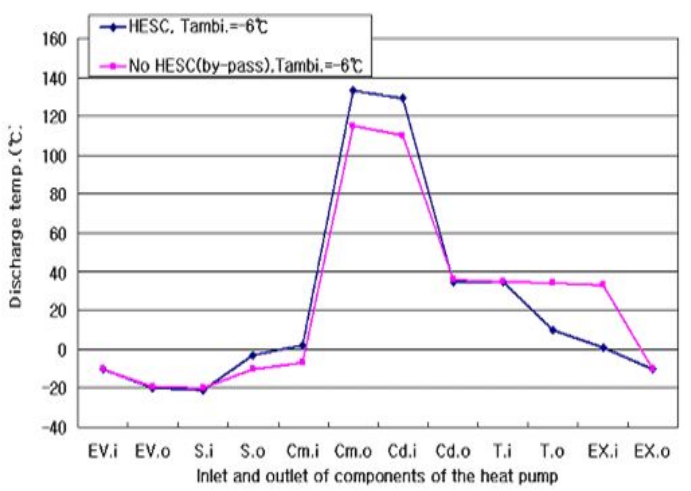

Figure 5. Inlet and outlet refrigerant temperature of mainof the heat pump circuit.
As shown in Fig.5, the temperature difference between the suction and discharge of compressor was $135^{\circ} \mathrm{C}$ when the refrigerant passed through the HESC at the ambient temperature of $-6^{\circ} \mathrm{C}$, and in case of by-pass (not passing through HESC) the temperature difference between the suction discharge of compressor was $120^{\circ} \mathrm{C}$ at ambient temperature of $-6^{\circ} \mathrm{C}$.

Therefore, the effect of the HESC on the increase of compressor discharge temperature was $15^{\circ} \mathrm{C}$.

At the ambient temperature of $-6^{\circ} \mathrm{C}$, the temperature difference between the inlet and outlet of condenser was $92^{\circ} \mathrm{C}$ in the refrigerant circuit passing through the HESC. Under the same condition, however, that was $72^{\circ} \mathrm{C}$ in the refrigerant circuit passing through by-pass.

Therefore, the effect of the HESC on the temperature increase of was $20^{\circ} \mathrm{C}$.

These results showed that the COP of the air to water heat pump system could be increased by the HESC.

\subsection{Water temperature variation with the water mass flow rate}

Fig.6 shows the temperature variation of the water heated by condenser of the heat pump system according to the water mass 
flow rate.

As shown in Fig.6, in case of the inlet water temperature of $15^{\circ} \mathrm{C}$, the temperature of the water heated by the condenser decreased curvedly with the increase of the water mass flow rate.

The water temperature decreased from $58^{\circ} \mathrm{C}$ to $27^{\circ} \mathrm{C}$ when the water mass flow rate increased from $100 \ell / \mathrm{hr}$ to $400 \ell / \mathrm{hr}$.

Consequently, the temperature variation of the water heated by the condenser could be controlled by the water mass flow rate.

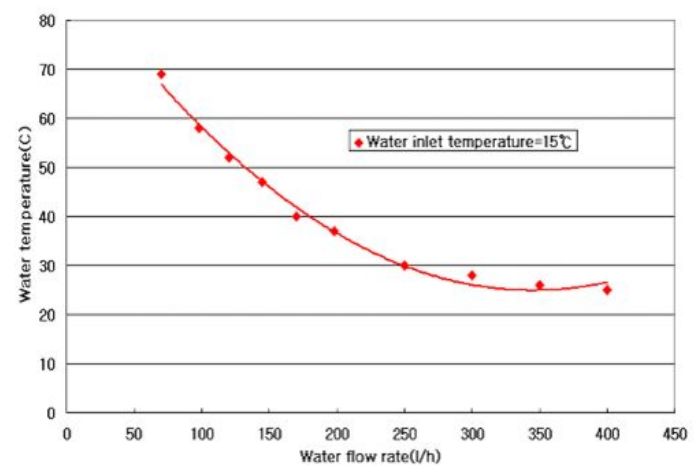

Figure 6. Water temperature variationwith the water mass flow rate

\subsection{HESC effect on the COP of heat pump system}

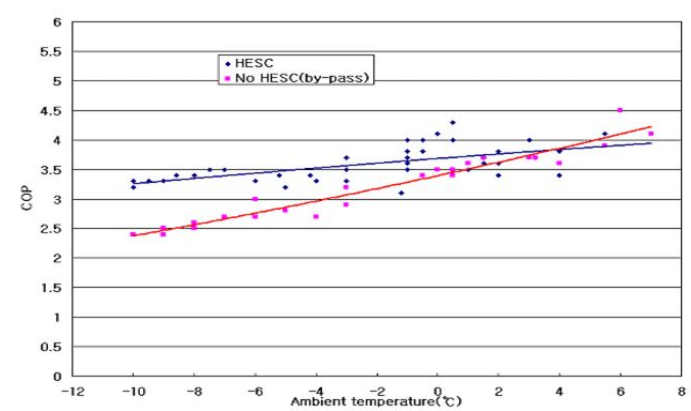

Figure 7. HESC effect on the COP of the heat pump system with the ambient temperature variation.
As shown in Fig.7, when the HESC was installed between the condenser and the evaporator of the heat pump circuit, the COP of the system was 3.2 at the ambient temperature of $-10^{\circ} \mathrm{C}$, but the COP of the system not passing the HESC was 2.4 under the same ambient conditions.

Consequently, the COP increased by the HESC was 0.8 , but at the ambient temperature above $4^{\circ} \mathrm{C}$, the COP of the system not passing the HESC (by-pass circuit) was higher than that of the system with the HESC. In other words, the COP of the system with the HESC was higher than that of the system not passing HESC (by-pass circuit), at the ambient temperature below $4^{\circ} \mathrm{C}$. Therefore, it is desirable to employ the HESC in the circuit of the heat pump system at the ambient temperature below $4^{\circ} \mathrm{C}$. In order to operate the heat pump system with or without the HESC, it was composed of two-way passes of the HESC and by-pass (Fig.1). Consequently, heat pump system could be operated in two ways according to the ambient temperature above and below $4^{\circ} \mathrm{C}$.

\section{Conclusion}

In general, the energy storage system is inevitable for the solar energy utilization. Fortunately enough, the solar energy is stored abundantly in the air, the earth and the water.

Unfortunately, however, the temperature variation of the solar energy stored in the ambient air according to the regions and seasons is one of the troubled factors for the realization of solar energy systems.

In case of the heat pump system using the energy stored in the ambient air as the 
heat source, the performance would rapidly decrease below $-10^{\circ} \mathrm{C}$ of the ambient air temperature.

In this study, in order to solve these problems, the HESC was developed and adapted to the air-to-water heat pump system and the HESC effect on this system was analyzed and summarized as follows.

(1) Compressor discharge temperature of the heat pump system installed with the HESC was $20^{\circ} \mathrm{C}$ higher than that of the system without HESC (by-pass).

(2) At the ambient temperature of $-10^{\circ} \mathrm{C}$, the air-to-water heat pump system with the HESC could be operated at the COP of that was 0.8 higher than that of the system without it.

(3) At the ambient temperature below $4^{\circ} \mathrm{C}$, the COP of the system with the HESC was higher than that of the system without it, but at the ambient temperature above $4^{\circ} \mathrm{C}$ the COP of the system with the HESC was lower than that of the system without it. Therefore, it is desirable to operate the system with the HESC at the ambient temperature below $4^{\circ} \mathrm{C}$.

\section{Bibliography}

1. Baker M., , Design and Performance of a Residential Earth Heat ASHRAE Trans, vol.11, n², 1953.

2. Chapon C., Delandre M., Air Conditioning by Heat Pump onWater Loop, ASHRAE Trans, vol.97, n 1991.

3. Ito S., Miura N., Takano Y., Studies of Heat Pumps Using Direct Expansion Type Solar Collector, Transaction of the ASME, Vol. 127, pp.60-64, 2005.
4. Ji J., Pei G., Chow T.T., Experimental Study of Photovoltaic Solar Assisted Heat Pump System, Solar Energy, Vol. 82, pp.43-52, 2008.

5. Karagiorgas M., Galatis K., Tragouri M., Tsoutsos T., Valaskakis A. B., Solar Assisted Heat Pump on Air Collectors: A Simulation Tool, ISES, vol. 84, n¹, 2010.

6. Xu G., Zhang X., Deng S., A Simulation on the Operating Performance of a Solar Air Source Heat Pump Water Heater, Applied Thermal Engineering, vol. 26, pp.1257-1265, 2006.

7. Xu G.Y., Xu X.J., Zhan X.S., Development and Performance Analysis on a PhotovoltaicThermal Integrated Heat Pump Water Heating System, In Proceedings of ISES Solar World Congress, Tsinghua University Beijing China, pp.2023-2026, 2007.

8. Stefanuk, N.B.M., Modeling and slmulation of a water-to-water heat pump incorporating superheat control, M.A.Sc, Thesis, University of Waterloo, Ontario, Canada, 1990 